Jurnal Care Vol .5, No 2,Tahun 2017

\title{
TINGKAT PENGETAHUAN, POLA KEBIASAAN LINGKUNGAN HIDUP BERHUBUNGAN DENGAN MOTIVASI IBU DALAM MEMILIH KONDISI GARAM
}

\author{
Vivin Yuni Astutik \\ Diploma 4 Kebidanan Universitas Tribhuwana Tunggadewi \\ e-mail : vivinyuniastutik@gmail.com
}

\begin{abstract}
Salt is one of food complement needs and is a source of electrolytes for the buman body. Iodine that added to salt has a beneficial effect on health. Iodine is a micro mineral substance that must be available in the body that works for thyroid bormone formation and is useful for metabolic processes in the body, growth, development, and brain function. Impairment due to iodine deficiency is one of micro nutrients problems in Indonesia that have a direct or indirect impact on the survival and quality of human resources. This research purpose is to know the relationship of awareness level, pattern of environmental habits and mother motivation in choosing salt condition for family food. This research is a kind of quantitative research. The population was 42 bousewives in RT 01 RW 02 Polagan Sampang Village neighborbood area. A sample of 42 people was obtained with total population sampling technique. Data analysis using multiple linear regression model. The data analysis results showed that the awareness level and pattern of environmental habits related to the mother's motivation in choosing the condition of salt.
\end{abstract}

Keywords: salt condition, motivation, awareness, pattern of environmental habits

\begin{abstract}
ABSTRAK
Garam merupakan salah satu kebutuhan yang merupakan pelengkap dari kebutuhan pangan dan merupakan sumber elektrolit bagi tubuh manusia. Yodium yang ditambahkan ke garam memberikan dampak yang baik bagi kesehatan. Yodium merupakan zat mineral mikro yang harus tersedia didalam tubuh yang berfungsi untuk pembentukan hormon tiroid dan berguna untuk proses metabolisme di dalam tubuh, pertumbuhan, perkembangan, dan fungsi otak. Gangguan akibat kekurangan yodium (GAKY) merupakan salah satu masalah gizi mikro di Indonesia yang mempunyai dampak langsung ataupun tidak langsung pada kelangsungan hidup dan kualitas sumber daya manusia. Tujuan dari penelitian ini adalah untuk mengetahui hubungan tingkat pengetahuan, pola kebiasaan lingkungan hidup dan motivasi ibu dalam memilih kondisi garam untuk makanan keluarga.Penelitian ini merupakan jenis penelitian kuantitatif. Populasi adalah semua ibu rumah tangga di Lingkungan Wilayah RT 01 RW 02 Desa Polagan Sampang yaitu sebanyak 42 orang. Sampel sebanyak 42 orang didapatkan dengan teknik sampling total populasi. Analisa data dengan menggunakan model regresi linier berganda. Hasil analisis data menunjukan bahwa
\end{abstract}


tingkat pengetahuan dan pola kebiasan lingkungan hidup berhubungan dengan motivasi ibu dalam memilih kondisi garam.

Kata Kunci : Kondisi garam, motivasi, pengetahuan, pola kebiasaan lingkungan hidup

\section{PENDAHULUAN}

Garam merupakan salah satu kebutuhan yang merupakan pelengkap dari kebutuhan pangan dan merupakan sumber elektrolit bagi tubuh manusia. Walaupun Indonesia termasuk negara penghasil garam, tetapi untuk kebutuhan garam dengan kualitas baik masih banyak diimpor dari luar negeri, terutama dalam hal ini garam beryodium serta garam industri (Sasongkowati, 2014).

Di Indonesia walaupun merupakan negara kepulauan, tetapi pusat pembuatan garam terkonsentrasi di Jawa dan Madura yaitu di Jawa seluas 14.231 Ha Jawa Barat $1.159 \mathrm{Ha}$, Jawa Tengah 5.168 Ha, Jawa Timur $6.904 \mathrm{Ha}$ ) dan Madura 15.347 Ha (Sumenep 10.067 Ha, Pemekasan 3.075 Ha, Sampang2.205 Ha). Luas areal yang dikelola oleh PT Garam hanya $5.116 \mathrm{Ha}$ yang seluruhnya berada di pulau Madura yaitu di Sumenep 3.163 Ha, Pemekasan 907 Ha dan di Sampang 1.046 Ha. Lokasi lainnya yaitu di NTB seluas $1.155 \mathrm{Ha}$, Sulawesi Selatan 2.040 $\mathrm{Ha}$, Sumatera dan lain-lain $1.885 \mathrm{Ha}$, sehingga luas areal penggaraman seluruhnya sebesar $30.658 \mathrm{Ha}$ dimana 25.542 Ha dikelola secara tradisional oleh rakyat. Areal garam yang dikelola oleh PT. Garam produksinya 60 ton $/ \mathrm{Ha} /$ tahun, sedang garam rakyat hanya 40 ton $/ \mathrm{Ha} /$ tahun (PT. Garam Persero, 2000).

Yodium merupakan zat mineral mikro yang harus tersedia didalam tubuh yang berfungsi untuk pembentukan hormon tiroid dan berguna untuk proses metabolisme di dalam tubuh. Gangguan akibat kekurangan yodium (GAKY) merupakan salah satu masalah gizi mikro di Indonesia yang mempunyai dampak langsung ataupun tidak langsung pada kelangsungan hidup dan kualitas sumber daya manusia (Almatsier, 2003).

Kekurangan yodium pada ibu hamil dapat menyebabkan abortus, bayi lahir mati, kelainan bawaan pada bayi yang akan dilahirkan, meningkatkan angka kematian prenatal, serta akan melahirkan bayi yang kretin dengan retardasi mental, pendek, muka dan tangan sembab serta terjadi 
kelemahan otot (Supariasa, 2001). Dampak GAKY lainnya yaitu hipertiroid, jika pada ibu hamil akan mengakibatkan bayi yang dikandungnya akan lahir dengan hipertiroidisme neonatal, berat badan lahir rendah dan kemungkinan besar juga akan mengalami cacat bawaan. Pemeriksaan tiroid pada ibu hamil saat awal kehamilan sangat diperlukan untuk mendeteksi ada tidaknya gangguan, sehingga ibu dan anak yang akan dilahirkan dalam keadaan sehat dan tidak mengalami kelainan (Supadmi dkk, 2007).

Cara penambahan garam pada saat memasak juga akan mempengaruhi jumlah yodium pada suatu masakan. Kehilangan yodium pada saat proses pemasakan dapat dikurangi. Cahyadi (2006), menyatakan bahwa dengan tiga cara perlakuan penambahan garam beryodium ke dalam sediaan makanan yaitu sebelum pemasakan, pada saat pemasakan dan pada saat siap disajikan, menunjukkan hasil persentase penurunan yodat tertinggi dengan cara penambahan sebelum pemasakan yakni sebesar 68,20\%-61,90\% dan yang terkecil dengan cara penambahannya saat akan disajikan yaitu $19,5 \%$.
Faktor yang berpengaruh terhadap kejadian GAKY adalah asupan yodium, tingkat pendidikan, pengetahuan, pekerjaan, cara perlakuan garam yodium seperti penyimpanan dan pengolahan serta faktor kebiasaan lingkungan hidup yaitu manusia yang terbiasa mengkonsumsi garam yang tidak beryodium dikarenakan cara mendapatkan garam tersebut lebih mudah dan lebih murah. Pengetahuan merupakan faktor yang sangat penting dalam terbentuknya suatu tindakan seseorang. Pengetahuan tentang gizi dapat menentukan dalam pemilihan makanan, apabila pengetahuan seseorang rendah maka akan menyebabkan pemilihan makanan yang salah.Bertambahnya pengetahuan mengenai gizi, menyebabkan seseorang akan mampu untuk menerapkan informasi yang telah didapatkannya dalam kehidupan sehari-hari. Pengetahuan merupakan tahapan awal untuk mengambil suatu keputusan, dimana pada akhirnya seseorang akan melakukan atau tidak seperti pengetahuan yang telah dimilkinya. Semakin bertambahnya pengetahuan seseorang, maka diharapkan 
status gizinya juga akan menjadi lebih baik (Wardani, 2009).

Universal Salt Iodization (USI) merupakan tujuan program nasional dalam mengatasi GAKY. Target dari USI yaitu konsumsi garam beryodium 90 persen. Pemerintah menargetkan pencapaian USI pada tahun 2010. Berdasarkan hasil Riskesdas tahun 2007, konsumsi garam mengandung yodium cukup ( $\geq 30 \mathrm{ppm}$ ) hanya 62.3 persen, masih jauh dari target USI (Depkes RI, 2008). Sedangkan untuk daerah Sampang pada tahun 2015, tingkat konsumsi garam yang mengandung cukup yodium sebesar $44,6 \%$ dan konsumsi garam yang mengandung kurang yodium sebesar 54,4\% (Dinkes Sampang, 2015).

Berdasarkan studi pendahuluan yang dilakukan di wilayah RT 01 RW 02 didapatkan bahwa hampir semua ibu rumah tangga menggunakan garam non yodium. Hal ini dikarenakan kebiasaan masyarakat mengkonsumsi garam yang diperoleh dari petani tambak garam dengan harga yang lebih murah bahkan ada yang mendapatkan secara gratis, serta kesadaran masyarakat tentang manfaat garam beryodium masih rendah. Oleh karena itu peneliti tertarik untuk melakukan penelitian tentang hubungan tingkat pengetahuan, pola kebiasaan lingkungan hidup dan motivasi ibu dalam memilih kondisi garam untuk makanan keluarga di wilayah RT 01 RW 02 Desa Polagan, Sampang.

\section{METODE PENELITIAN}

Penelitian ini merupakan jenis penelitian kuantitatif dengan menggunakan pendekatan cross sectional yaitu untuk mengetahui adanya hubungan antara variabel dependen dengan variabel independen (Notoatmojo, 2010). Populasi adalah keseluruhan objek penelitian atau objek yang akan diteliti (Notoatmodjo, 2003). Populasi dalam penelitian ini adalah semua Ibu rumah tangga di Lingkungan Wilayah RT 01 RW 02 desa Polagan Sampang yaitu sebanyak 42 orang. Sampel dalam penelitian ini sebanyak 42 Ibu rumah tangga. Teknik Pengambilan sampel pada penelitian ini adalah menggunakan total sampling, yaitu dengan mengambil semua anggota populasi menjadi sampel (Alimul, 2007). Dalam penelitian ini peneliti mengambil semua populasi menjadi sampel yaitu 
sebanyak 42 ibu rumah tangga. Analisa data menggunakan persamaan regresi linier berganda. Untuk menguji pengaruh variabel bebas dan terikat secara bersamasama digunakan pendekatan analisis ragam regresi.

\section{HASIL}

Tabel 1. Karakteristik Pendidikan Responden di Wilayah RT 01 RW 02 Desa Polagan Sampang

\begin{tabular}{lcc}
\hline Pendidikan & Jumlah & $\%$ \\
\hline SD & 32 orang & 76.19 \\
SMP & 6 orang & 14.29 \\
SMA & 2 orang & 4.76 \\
S1 & 2 orang & 4.76 \\
\hline TOTAL & 42 orang & 100 \\
\hline
\end{tabular}

Berdasarkan Tabel 1 diketahui bahwa sebagian besar responden berpendidikan Sekolah Dasar (SD) yakni 32 orang $(76,19 \%)$.

Tabel2. Karakteristik Pekerjaan Responden Wilayah RT 01 RW 02 Desa Polagan Sampang

\begin{tabular}{lcc}
\hline Pekerjaan & Jumlah & $\%$ \\
Ibu Rumah Tangga & 38 & 90.48 \\
Honorer & 1 & 2.38 \\
Swasta & 1 & 2.38 \\
Petani & 1 & 2.38 \\
Pedagang & 1 & 2.38 \\
\hline TOTAL & 42 & 100 \\
\hline
\end{tabular}

Berdasarkan Tabel 2 diketahui bahwa sebagian besar responden sebagai ibu rumah tangga yakni 38 orang( $(90,48 \%)$.

\section{Analisis Hasil Pengujian}

Analisis statistik penelitian ini untuk mengetahui hubungan tingkat pengetahuan, pola kebiasaan lingkungan hidup dan motivasi ibu dalam memilih kondisi garam untuk makanan keluarga di wilayah RT 01 RW 02 Desa Polagan maka untuk hasil analisis disajikan pada Tabel 3.

Berdasarkan yang disajikan pada Tabel 3 diatas, dapat diketahui bahwa rata-rata pengetahuan $\left(\mathrm{X}_{1}\right)$ sebesar 5,952 dengan nilai terkecil 4 dan nilai terbesar 10 dengan standar deviasi sebesar 2,2191, rata-rata pola kebiasaan lingkungan hidup $\left(\mathrm{X}_{2}\right)$ sebesar 5,667 dengan nilai terkecil 3 dan nilai terbesar 12 dengan standar deviasi sebesar 2,2049, rata-rata Motivasi $\left(\mathrm{X}_{3}\right)$ sebesar 5,548 dengan nilai terkecil 4 dan nilai terbesar 10 dengan standar deviasi sebesar 1,9406, dan rata-rata pada Kondisi Garam (Y) sebesar 5,786 dengan nilai terkecil 4 dan nilai terbesar 9 dengan standar deviasi sebesar 2,1131. 
Persamaan regresi linier berganda hasil analisa tersebut adalah sebagai berikut:

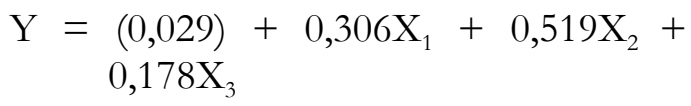

Pada persamaan regresi linier berganda tersebut, koefisien regresi korelasinya bernilai positif $(+)$. Hal ini menunjukkan bahwa variabel tingkat pengetahuan (X1) berhubungan dengan kondisi garam dengan koefisien regresi 0,306 yang artinya semakin tinggi tingkat pengetahuan maka semakin baik pula dalam memilih kondisi garam yang sehat.

Tabel 3. Deskriptif Statistik dari Hubungan Tingkat Pengetahuan, Pola Kebiasaan Lingkungan Hidup dan Motivasi Ibu dalam memilih Kondisi Garam untuk Makanan Keluarga di wilayah RT 01 RW 02 Desa Polagan

\begin{tabular}{lcccc}
\hline Variabel & Rata-Rata & Terkecil & Terbesar & Standar Deviasi \\
\hline Tingkat & 5.952 & 4 & 10 & 2.2191 \\
$\begin{array}{l}\text { Pengetahuan }\left(\mathrm{X}_{1}\right) \\
\text { Pola Kebiasaan }\end{array}$ & 5.667 & 3 & 12 & 2.2049 \\
Lingkungan Hidup & & & & \\
$\left(\mathrm{X}_{2}\right)$ & & & & \\
Motivasi $\left(\mathrm{X}_{3}\right)$ & 5.548 & 4 & 10 & 1.9406 \\
Kondisi Garam $(\mathrm{Y})$ & 5.786 & 4 & 9 & 2.1131 \\
\hline
\end{tabular}

Variabel pola kebiasaan lingkungan hidup (X2) dengan koefisien regresi 0,519 juga mempunyai hubungan dengan kondisi garam yang artinya semakin tinggi pola kebiasaan lingkungan hidup maka semakin tinggi pula dalam memilih kondisi garam yang tersedia di sekitar lingkungan hidup tersebut. Dan pada variabel motivasi (X3) dengan koefisien regresi 0,178 juga mempunyai hubungan dengan kondisi garam yang artinya semakin tinggi motivasi yang ada maka semakin tinggi pula dalam memilih kondisi garam yang akan digunakan.

Tabel 4. Hasil Analisis Ragam Regresi Linier Berganda Hubungan Tingkat Pengetahuan, Pola Kebiasaan Lingkungan Hidup dan Motivasi Ibu dalam memilih Kondisi Garam untuk Makanan Keluarga di wilayah RT 01 RW 02 Desa Polagan

\begin{tabular}{llllll}
\hline $\begin{array}{l}\text { Sumber } \\
\text { Variasi }\end{array}$ & $\begin{array}{l}\text { Derajat } \\
\text { Bebas }\end{array}$ & $\begin{array}{l}\text { Jumlah } \\
\text { Kuadran }\end{array}$ & $\begin{array}{l}\text { Kuadran } \\
\text { Tengah }\end{array}$ & $\mathrm{F}_{\text {hitung }}$ & $\mathrm{F}_{0,05}$ \\
\hline Regresi & 161,016 & 3 & 53,672 & 92,473 & 2,85 \\
Galat & 22,055 & 38 & 0,580 & & \\
\hline Total & 183,071 & 41 & & & \\
\hline
\end{tabular}


Berdasarkan Tabel 4 hasil analisa ragam regresi linier berganda dapat disimpulkan bahwa nilai $\mathrm{F}_{\text {hitung }}>\mathrm{F}_{0,05}$ yaitu 92,473> 2,85 hal ini menunjukkan bahwa variabel tingkat pengetahuan $\left(\mathrm{X}_{1}\right)$, pola kebiasaan lingkungan hidup $\left(\mathrm{X}_{2}\right)$ dan motivasi $\left(\mathrm{X}_{3}\right)$ secara bersama - sama mempunyai hubungan yang signifikan terhadap variabel Kondisi Garam (Y).

Tabel 5. Nilai Koefisien Regresi, Standar Eror, $\mathrm{T}_{\text {hitung }}$ dan nilai $\mathrm{T}$ tabel dari Hubungan Tingkat Pengetahuan, Pola Kebiasaan Lingkungan Hidup dan Motivasi Ibu dalam memilih Kondisi Garam untuk Makanan Keluarga di wilayah RT 01 RW 02 Desa Polagan

\begin{tabular}{|c|c|c|c|c|}
\hline Variabel & $\begin{array}{l}\text { Koefisien } \\
\text { Regresi } \\
\text { (R Square) }\end{array}$ & $\begin{array}{l}\text { Standar } \\
\text { Eror }\end{array}$ & $\mathrm{t}_{\text {hitung }}$ & $\mathrm{t}_{0,05}$ \\
\hline Variabel $\mathrm{X}_{1}, \mathrm{X}_{2}, \mathrm{X}_{3}$ terhadap Y & 0,808 & & & 1,686 \\
\hline Pendidikan $\left(\mathrm{X}_{1}\right)$ terhadap Y & 0,275 & 0,156 & 2,647 & \\
\hline Sosial Budaya $\left(\mathrm{X}_{2}\right)$ terhadap $\mathrm{Y}$ & 0,284 & 0,146 & 3,065 & \\
\hline $\begin{array}{l}\text { Status Sosial Ekonomi }\left(\mathrm{X}_{3}\right) \\
\text { terhadap Y }\end{array}$ & 0,249 & 0,149 & 2,214 & \\
\hline
\end{tabular}

Berdasarkan Tabel 5 diatas menunjukkan bahwa nilai $\mathrm{t}$ hitung variabel $\mathrm{X}_{1}$ sebesar 2,647, variabel $\mathrm{X}_{2}$ sebesar 3,065, dan variabel $\mathrm{X}_{3}$ sebesar $2,214>\mathrm{t}_{0,05}(1,686)$ hal ini berarti menunjukkan bahwa ada hubungan yang signifikan antara Tingkat Pengetahuan $\left(\mathrm{X}_{1}\right)$, Pola Kebiasaan Lingkungan Hidup $\left(\mathrm{X}_{2}\right)$ dan Motivasi $\left(\mathrm{X}_{3}\right)$ dengan kondisi garam (Y). Adapun variabel bebas yang paling dominan mempunyai hubungan dengan kondisi garam adalah Pola Kebiasaaan Lingkungan Hidup $\left(\mathrm{X}_{2}\right)$, hal ini dapat dilihat dari $\mathrm{t}_{\text {hitung }}>\mathrm{t}_{\text {tabee }}$ yaitu 3,065.
Dari nilai koefisien regresi ( $\mathrm{R}$ Square) diketahui bahwa hubungan tingkat pengetahuan $\left(\mathrm{X}_{1}\right)$, pola kebiasaan lingkungan hidup $\left(\mathrm{X}_{2}\right)$ dan motivasi $\left(\mathrm{X}_{3}\right)$ sebesar 0,808 (80,8\%). Nilai koefisien regresi ( $\mathrm{R}$ Square) variabel tingkat pengetahuan $\left(\mathrm{X}_{1}\right)$ terhadap kondisi garam (Y) sebesar 27,5 \%, nilai koefisien determinasi ( $\mathrm{R}$ Square) variabel pola kebiasaan lingkungan hidup $\left(\mathrm{X}_{2}\right)$ terhadap kondisi garam $(\mathrm{Y})$ sebesar 28,4\% dan nilai koefisien determinasi ( $\mathrm{R}$ Square) variabel motivasi terhadap kondisi garam (Y) sebesar 24,9\%. Dengan demikian dapat disimpulkan bahwa variabel pola 
kebiasaan lingkungan hidup $\left(\mathrm{X}_{2}\right)$ mempunyai hubungan yang lebih kuat terhadap kondisi garam $(\mathrm{Y})$ dengan nilai R square sebesar $28,4 \%$.

\section{PEMBAHASAN}

Pada persamaan regresi linier didapatkan bahwa nilai koefisien regresi $\mathrm{X}_{1}, \mathrm{X}_{2}, \mathrm{X}_{3}$ bernilai positif $(+)$ artinya ada hubungan positif dari variabel independent (Tingkat pengetahuan, pola kebiasaan Lingkungan Hidup dan Motivasi) terhadap variabel dependent (kondisi garam) yang artinya apabila variabel independen meningkat maka variabel dependent juga meningkat.

Dari hasil analisa ragam regresi linier berganda dapat disimpulkan bahwa nilai $\mathrm{F}_{\text {hitung }}>\mathrm{F}_{0,05}$ yaitu $92,473>2,85$ hal ini menunjukkan bahwa variabel Tingkat Pengetahuan $\left(\mathrm{X}_{1}\right)$, Pola Kebiasaan Lingkungan Hidup $\left(\mathrm{X}_{2}\right)$ dan Motivasi $\left(\mathrm{X}_{3}\right)$ secara bersama - sama mempunyai hubungan yang signifikan terhadap variabel Kondisi Garam (Y).

Dari nilai $t$ hitung variabel (Tingkat Pengetahuan) $\mathrm{X}_{1}>\mathrm{t}_{0,05}$ yaitu 2,647> 1,686 hal ini berarti menunjukkan bahwa ada hubungan yang signifikan antara Tingkat Pengetahuan dengan kondisi garam. Pengukuran pengetahuan dapat dilakukan dengan wawancara atau angket yang menanyakan tentang isi materi yang ingin diukur dari subjek penelitian atau responden (Notoatmodjo, 2012). Hasil yang didapatkan adalah sebagian besar responden mempunyai pengetahuan yang rendah dalam memilih kondisi garam yang digunakan, karena sebanyak 35 orang masih menggunakan garam non yodium.

Setelah dilakukan pengujian terhadap garam yang digunakan dengan menggunakan tes larutan Yodida menunjukkan hasil tidak ada perubahan warna pada garam, garam tidak berwarna biru keunguan tetapi tetap berwarna putih. Hal ini menunjukkan bahwa garam yang masyarakat gunakan mengandung 0 ppm, artinya tidak mengandung yodium. Hal ini dilatarbelakangi oleh pendidikan mereka yang masih rendah, sebanyak 32 orang berpendidikan Sekolah Dasar (SD). Pengetahuan sangat erat kaitannya dengan pendidikan dimana diharapkan seseorang dengan pendidikan tinggi, orang tersebut akan semakin luas pula 
Jurnal Care Vol .5, No 2,Tahun 2017

pengetahuannya. Namun, perlu diungkapkan oleh Adi Asmara, (2008) ditekankan bahwa orang yang bahwa Lingkungan hidup merupakan berpendidikan rendah tidak berarti mutlak berpengetahuan rendah pula (Budiman, 2014). Karena dalam penelitian ini juga ditemui responden yang berpendidikan rendah tapi menunjukkan sikap positif dalam memilih kondisi garam yaitu menggunakan garam yodium. Hal ini dibuktikan dengan melakukan pengujian terhadap garam menggunakan tes larutan Yodida. Setalah ditetesi 2-3 tetes larutan Yodida didapatkan hasil adanya perubahan warna dari garam dari putih menjadi biru keunguan, artinya garam tersebut mengandung 30-80 ppm dan mengandung yodium. Akan tetapi, sebaliknya meskipun responden berpendidikan tinggi tapi masih menggunakan garam non yodium, hal ini dikarenakan kebiasaan perilaku dalam mengkonsumsi garam non yodium.

Dari nilai $\mathrm{t}_{\text {hitung }}$ variabel (Pola Kebiasaan Lingkungan Hidup) $\mathrm{X}_{2}>\mathrm{t}_{0,05}$ yaitu 3,065 $>$ 1,686 hal ini berarti menunjukkan bahwa ada hubungan yang signifikan antara pola kebiasaan lingkungan hidup dengan kondisi garam sebagaimana ekologi terapan dengan tujuan agar manusia dapat menerapkan prinsip dan konsep pokok ekologi dalam lingkungan hidup. Manusia merupakan mahluk yang paling dominan terhadap ekosistem dibumi. Dalam penelitian ini didapatkan hasil bahwa pola kebiasaan lingkungan hidup merupakan variabel yang paling dominan diantara variabel lainnya, hal ini dikarenakan dilingkungan tempat peneliti tersedia banyak lahan untuk pembuatan garam sendiri sehingga banyak masyarakat disekitar dengan mudah dan dengan harga yang lebih murah dalam mendapatkan garam non yodium dari petani garam bahkan ada yang mendapatkannya secara gratis. Oleh karena itu banyak masyarakat yang menggunakan garam non yodium, karena lingkungan sekitar sangat mendukung tersedianya garam non yodium.

Sedangkan nilai $t_{\text {hitung }}$ variabel (Motivasi) $\mathrm{X}_{3}>\mathrm{t}_{0,05}$ yaitu 2,214 $>1,686$ hal ini berarti menunjukkan bahwa ada hubungan yang signifikan antara motivasi dengan kondisi garam sebagaimana diungkapkan oleh Sardiman (2012) bahwa 
motivasi akan menyebabkan terjadinya suatu perubahan energi yang ada pada diri manusia, kemudian bertindak atau melakukan sesuatu. Semua ini didorong karena adanya tuntutan, kebutuhan atau keinginan. Adanya keinginan dari dalam dirinya sendiri untuk menggunakan garam non yodium dikarenakan kebiasaan dari keluarga secara turun temurun dan kebiasaan masyarakat sekitar menggunakan garam non yodium yang didapatkan dari petani garam dengan harga yang lebih murah. Kurangnya peran tenaga kesehatan dalam memberikan motivasi terhadap masyarakat untuk menggunakan garam yodium membuat masyarakat tetap menggunakan garam non yodium, hal ini dikarenakan sebagian besar masyarakat mengaku tidak pernah mendapatkan penyuluhan tentang garam yodium.

Dan dilihat dari nilai koefisien determinasi ( $\mathrm{R}$ Square) variabel Tingkat Pengetahuan $\left(\mathrm{X}_{1}\right)$ terhadap kondisi garam (Y) sebesar 27,5 \%, nilai koefisien determinasi ( $\mathrm{R}$ Square) variabel Pola Kebiasaan Lingkungan Hidup $\left(\mathrm{X}_{2}\right)$ terhadap kondisi garam (Y) sebesar $28,4 \%$ dan nilai koefisien determinasi
(R Square) variabel motivasi terhadap kondisi garam (Y) sebesar 24,9 \%. Dengan demikian dapat disimpulkan bahwa variabel Pola Kebiasaan Lingkungan Hidup $\left(\mathrm{X}_{2}\right)$ mempunyai hubungan yang lebih kuat terhadap kondisi garam ( $\mathrm{Y}$ ) dengan nilai $\mathrm{R}$ square sebesar $28,4 \%$.

\section{KESIMPULAN}

1. Ada hubungan tingkat pengetahuan, pola kebiasaan lingkungan hidup dan motivasi kondisi garam.

2. Ada hubungan yang signifikan antara tingkat pengetahuan dengan kondisi garam

3. Ada hubungan yang signifikan antara motivasi dengan kondisi garam

4. Variabel Pola Kebiasaan Lingkungan Hidup $\left(\mathrm{X}_{2}\right)$ mempunyai hubungan yang lebih kuat terhadap kondisi garam ( $\mathrm{Y}$ ) dengan nilai $\mathrm{R}$ square sebesar $28,4 \%$.

\section{REFERENSI}

Alimul, A. (2007). Metode Penelitian Kebidanan dan Teknik Analisa Data. Jakarta, Salemba Medika. 
Jurnal Care Vol .5, No 2,Tahun 2017

Almatsier, Sunita.(2003). Prinsip Dasar

Ilmu Gizi. Jakarta, PT. Gramedia

Pustaka Utama

Asmara, Adi. (2008). Pendidikan

Lingkungan Hidup untuk

SMP/MTs kelas VIII. Jakarta,

CV. Atika Mandiri.

Depkes RI. (2003). Pedoman Umum Gizi

Seimbang (Panduan untuk Petugas).

Jakarta, Bakti Husada.
Notoatmodjo, S. (2010) Metodologi

Penelitian Kesehatan. Jakarta, Rineka Cipta.

Notoatmodjo, S.(2003). Pendidikan dan Perilaku Kesehatan. Jakarta, Rhineka Cipta.

Supariasa,IN,dkk.(2001). Penilaian Status Gizi. Jakarta, EGC. 